\title{
WYBRANE ASPEKTY ADMINISTROWANIA EWIDENCJA DOROBKU NAUKOWEGO PRACOWNIKÓW WYŻSZYCH UCZELNI TECHNICZNYCH W POLSCE
}

\section{Abstract \\ Selected aspects of administering the record of scientific achievements of employees of technical universities in Poland}

The article presents the issue of register of literary scientific achievements of research workers with particular focus on the activities of selected technical university libraries. The article has been divided into two parts - theoretical and empirical. In the first part, sources of scientific information like: a bibliography of university staff publications, institutional repository, Poland Scientific Bibliography, has been presented. The second part presents the results of research on the procedure for registration of scientific achievements of alma mater employees in the bibliography of university staff publications and institutional repository. These studies were based on review of internal rector ordinances, other university legal acts and information about resources documentation in the above sources, which are available on the websites of selected technical university libraries. In addition, rector ordinances relating to the facilitation of the preparation of citations have also been taken into account. An overview of websites was made in July, 2016.

Keywords: universities, scientific achievements of research workers, legal regulations, Poland Bibliography Scientific, Institutional Repository 


\section{Streszczenie}

W artykule przedstawiono problematykę ewidencji piśmienniczego dorobku naukowego pracowników naukowych, ze szczególnym uwzględnieniem działalności bibliotek wybranych wyższych uczelni technicznych. Artykuł podzielono na dwie części: teoretyczną i empiryczną. W pierwszej przybliżono źródła informacji naukowej: bibliografia publikacji pracowników uczelni, repozytorium instytucjonalne i Polska Bibliografia Naukowa. W części drugiej zaprezentowano wyniki badań dotyczących procedury ewidencji dorobku naukowego pracowników macierzystej uczelni w bibliografii publikacji pracowników i repozytorium instytucjonalnym, na podstawie przeglądu zarządzeń wewnętrznych rektorów, innych uczelnianych aktów prawnych oraz informacji o dokumentowaniu zasobów w wyżej wymienianych serwisach dostępnych na stronach bibliotek wybranych uczelni technicznych. Zasygnalizowano zarządzenia rektorskie ułatwiające sporządzanie cytowań prac naukowych pracowników. Przeglądu stron dokonano w lipcu 2016 roku.

Słowa kluczowe: szkoły wyższe, dorobek naukowy pracowników, regulacje prawne, Polska Bibliografia Naukowa, repozytorium instytucjonalne

\section{Wprowadzenie}

Uczelnia wyższa jako organizacja działa w oparciu o szereg specyficznych zasobów przy uwzględnieniu prowadzenia działalności dydaktycznej i badawczej. Do zasobów uczelni można zaliczyć m.in.: kadrę, z podziałem na naukowców i pracowników administracyjnych, aparaturę naukowo-badawczą, zasoby biblioteczne, archiwa, budynki i budowle. Kompleksowe wykorzystywanie zasobów umożliwia uczelni efektywne funkcjonowanie [Gajda, Cichoń, 2015: 3].

Zauważa się, że nauczyciele akademiccy są przede wszystkim pracownikami naukowymi, prowadzącymi badania naukowe w swoich dyscyplinach, popularyzującymi własne dokonania w rozmaitych publikacjach [Cichoń, 2013: 71]. Publikacje stanowiące dorobek akademików podlegają ewidencji na uczelni. Zgodnie ze Słownikiem języka polskiego [Szymczak, 2002: 527] ewidencja rozumiana jest jako przygotowywanie wykazów i spisów, mających na celu ustalenie danych liczbowych dotyczących osób i ich aktywności. Podstawowym źródłem informacji o dorobku naukowców uczelni wyższej jest bibliografia publikacji jej pracowników, opracowywana przez bibliotekę zgodnie z procedurą ustaloną $\mathrm{m}$.in. $\mathrm{w}$ formie zarządzeń rektora. W okresie intensywnego rozwoju informacji naukowej w Internecie zaistniały m.in.: repozytoria instytucjonalne, zmiany w ewidencji dorobku piśmienniczego pracowników i obowiązek przekazywania tych informacji przez uczelnie do Polskiej Bibliografii Naukowej (PBN), będącej własnością Ministerstwa Nauki i Szkolnictwa Wyższego (MNiSW). Uczelnie, w tym biblioteki, stanęły przed koniecznością dostosowania bibliografii do współpracy z ogólnopolskim systemem informacji. Ujednolicenie wskazanych przez MNiSW szczegółowych elementów opisu bibliograficznego wybranych dokumentów wpłynęło na poprawę jakości i funkcjonalności bibliografii poszczególnych uczelni w bardzo krótkim 
czasie [Brzeziński i in., 2016]. Uczelnie techniczne, aczkolwiek stanowią oddzielną grupę wśród szkół wyższych [szerzej: Leja, 2013: 76-151] i w różny sposób rozwiązują problemy związane z prowadzeniem bibliografii publikacji pracowników naukowych, to jednak w jednym czasie zaczęły wprowadzać zmiany [Sójkowska, Barańska-Malinowska, 2011].

W tym kontekście w niniejszym artykule autorzy podjęli próbę przedstawienia organizacji pracy w zakresie ewidencji dorobku pracowników akademickich w bibliotekach wybranych uczelni technicznych. Artykuł podzielono na części teoretyczną i empiryczną. W pierwszej przybliżono w zarysie serwisy: bibliografia publikacji pracowników uczelni, repozytorium instytucjonalne i Polska Bibliografia Naukowa. W drugiej części zaprezentowano procedurę ewidencji piśmienniczego dorobku naukowego akademików w bibliografii publikacji pracowników uczelni i repozytorium instytucjonalnym na podstawie przeglądu uczelnianych aktów prawnych, ze szczególnym uwzględnieniem zarządzeń wewnętrznych rektorów oraz informacji o dokumentowaniu zasobów w wyżej wymienionych serwisach, dostępnych na stronach bibliotek wybranych uczelni technicznych. Zwrócono uwagę na zarządzenia rektorów ułatwiające sporządzanie analizy cytowań dorobku pracowników. Przeglądu stron bibliotek dokonano w lipcu 2016 roku.

\section{Bibliografia publikacji pracowników uczelni}

Najstarsze bibliografie publikacji pracowników uczelni technicznych dokumentują piśmienniczy dorobek okresu od połowy lat 40 . ubiegłego wieku. W bibliografiach pochodzących z początkowego okresu ich tworzenia opis publikacji zawiera podstawowe dane: autor, tytuł pracy, źródło publikacji, miejsce i rok wydania, liczba stron. Dane o dorobku naukowym pogrupowano zazwyczaj według jednostek uczelnianych, w ich obrębie według autora, a pomocniczy aparat wyszukiwawczy stanowi przede wszystkim alfabetyczny indeks autorski umieszczony na końcu dzieła. Wersje papierowe wydawane przez inne uczelnie pozyskiwały biblioteki głównie w drodze darów i/lub wymiany. W zależności od liczebności gromadzonych zasobów bibliografie opracowano w katalogu książek i/lub katalogu czasopism.

Zastosowanie technologii komputerowej umożliwiło wykazywanie informacji o pracownikach i ich dorobku w elektronicznych bazach danych. Dzięki temu część roczników udostępnia się na CD-ROM, a najnowsze zasoby wszystkich uczelni technicznych online. W niektórych bibliotekach roczniki archiwalne poddano digitalizacji i udostępniono w bibliotekach cyfrowych, jak m.in.: „Bibliografia Publikacji Pracowników Politechniki Śląskiej” za lata 1945-1981 w Bibliotece Cyfrowej Politechniki Śląskiej, „Bibliografia Publikacji Pracowników Politechniki Łódzkiej” za lata 1945-1989 w Łódzkiej Regionalnej Bibliotece Cyfrowej CYBRA.

Duże rozbieżności w prowadzeniu baz danych bibliografii wyższych uczelni technicznych, w szczególności w opracowaniu czasopism, udostępnianiu linków 
do pełnych tekstów online, jak i w stosowanym oprogramowaniu, wykazały badania przeprowadzone w 2011 roku [Sójkowska, Barańska-Malinowska, 2011].

Bez względu na poziom rozwoju bazy bibliografia służy dziś jako pomocnicze źródło informacji w ocenie dorobku naukowego naukowców, ocenie parametrycznej jednostek uczelnianych, sporządzaniu wykazów cytowań prac naukowych pracownika i w innych bieżących potrzebach uczelni. Te ostatnie wynikają z obowiązujących zasad oceny dorobku naukowego uczelni i zatrudnionych w niej naukowców oraz obowiązku przekazywania danych o dorobku pracowników do PBN będącej własnością MNiSW. W ocenie dorobku naukowego brane są pod uwagę różnego rodzaju wskaźniki oceny publikacji [szerzej: Knop, 2014], co powoduje konieczność uzupełniania opisu bibliograficznego dokumentów o dodatkowe dane typu: punktacja MNiSW, obecność na Master Journal List, Impact Factor, lista ERIH, oraz wykonywania analizy cytowań prac naukowych pracowników na podstawie rozmaitych źródeł internetowych. Jednym z podstawowych źródeł wskazanym przez MNiSW jest Web of Science, baza danych o zasięgu światowym. Sporządzanie analizy cytowań na podstawie Web of Science stwarza bibliotekarzom dużo problemów w przypadku nazwisk popularnych lub zapisanych w formie szczątkowej, niepełnych tytułów publikacji w bazie, braku opisu publikacji w bibliografii publikacji pracowników macierzystej uczelni, w szczególności afiliowanych do innej instytucji akademickiej.

W wyniku połączenia w 2011 roku Web of Science z portalem Researcher ID proces rozróżniania prac $\mathrm{w}$ bazie, głównie artykułów w czasopismach, został uproszczony przez wprowadzenie numeru ResearcherID jednoznacznie identyfikującego utwory danego autora. W celu uzyskania takiego numeru autor musi sam dokonać rejestracji na portalu (www.researcherid.com) i utworzyć swój profil. Obecność własnego numeru w opisach dokumentów dodawanych do Web of Science wymaga każdorazowo ich aktualizacji (dodania do założonego profilu) przez autora. Innymi słowy - zależy od aktywności samego autora.

\section{Repozytorium instytucjonalne}

Repozytorium instytucjonalne organizowane jest na potrzeby ewidencji i archiwizacji najnowszego dorobku pracowników naukowych uczelni publikowanego drukiem i wyłącznie online, służy także udostępnianiu go w Internecie i zabezpieczeniu go przed zniszczeniem. Jednocześnie stanowi narzędzie promujące uczelnię. W porównaniu z bibliografią publikacji pracowników odznacza się większym usieciowieniem, czyli większą liczbą powiązań z sieciowymi systemami informacyjnymi. Należy do pierwszych serwisów bibliotecznych, w których zasoby są dodawane przez autorów, co różni repozytorium od biblioteki cyfrowej [Bednarek-Michalska, 2013]. Przez samodzielną ewidencję własnych prac autorzy mają wpływ na poziom ich udostępniania, rozumiany różnie: poziom, na którym utwór jest dostępny dla użytkownika końcowego, oraz poziom, na którym utwór indeksują roboty Google. Dla użytkownika znaczenie ma, co 
przeczyta w Internecie: spis treści, streszczenie, fragment czy pełny tekst. Autorowi zależy (zazwyczaj) na szerokim oddziaływaniu tekstu, cytowaniu przez innych. Mając na uwadze indeksowanie zdeponowanego pliku PDF przez roboty Google, w literaturze przedmiotu wskazuje się na sposób eksponowania nazwiska autora, tytułu utworu, bibliografii w pracy naukowej, korzystnie regulujący ten proces [Karwasińska, Rychlik, 2011]. Ma to o tyle istotne znaczenie, że Google Scholar, jako narzędzie scalające zasoby naukowe i informacje o autorach, służy m.in. do sporządzania wykazów cytowań wraz z indeksem Hirscha.

Jednak możliwość ewidencji zasobów w repozytorium instytucjonalnym zależy od wielu czynników. Wymienia się popularyzowanie serwisu przez bibliotekarzy w środowisku akademickim, wsparcie inicjatywy przez wszystkich interesariuszy macierzystej uczelni i współpracę w kolejnych fazach jego projektowania, wdrożenia czy dalszego rozwoju [Karwasińska, Rychlik, 2011].

$\mathrm{Na}$ etapie projektowania serwisu istotny jest wybór struktury uwzględniający strukturę organizacyjną uczelni, czyli jednostki uczelniane typu wydział, jednostka ogólnouczelniana i inne, w zależności od schematu organizacyjnego danej szkoły wyższej. Ważny jest także podział zasobów na kolekcje: artykuły naukowe, materiały dydaktyczne, monografie, rozprawy doktorskie, prace dyplomowe, varia.

\section{Polska Bibliografia Naukowa}

Obowiązek wprowadzania danych do Polskiej Bibliografii Naukowej wchodzącej w skład elektronicznego Systemu Informacji o Szkolnictwie Wyższym POL-on dotyczy dorobku naukowego od 1 stycznia 2013 roku [Komunikat, 2015]. Na stronie internetowej portal opisany jest jako narzędzie do przechowywania i udostępniania informacji o polskich i zagranicznych czasopismach naukowych, publikacjach polskich naukowców ze wskazaniem funkcjonalności serwisu:

1) dzisiaj: dążenie do ogólnie dostępnej centralnej bibliografii naukowej wykazującej dorobek polskich pracowników naukowych i instytucji naukowych, złożenie ankiety czasopisma naukowego (w czasie tur ewaluacji czasopism naukowych), rozwój PBN w formie repozytorium;

2) w przyszłości: integracja z zasobami repozytoriów instytucjonalnych polskich uczelni i jednostek naukowych oraz formatowanie bibliografii osób i instytucji w sposób wymagany przez inne podmioty [O nas].

Rozważania teoretyczne podjęte w początkowym okresie powstania tej centralnej bibliografii, dotyczące tego, kto ma wprowadzać dane do systemu, pokazały zagadnienie jako złożone, do końca nieusystematyzowane [Kulczycki, 2012] i nierozpoznane w środowisku uczelni, a zatem wśród bibliotekarzy i naukowców. Informacja niebudząca wątpliwości to typy gromadzonych dokumentów (articleartykuły w czasopismach, book - książki i monografie, chapter - rozdziały w książkach) i ich opis bibliograficzny, opublikowane na stronie PBN [Szczegółowy opis formatu plików importu]. Jednak w praktyce wystąpiło wiele problemów w procesie w prowadzania danych. W literaturze podkreśla się, iż szczegółowa informacja, 
a także definicje pól określone w konkretnych aktach prawnych budziły wątpliwości interpretacyjne, które ciągle istnieją [Brzeziński i in., 2016]. Powstaje pytanie: jakie są zasady ewidencji w centralnej bibliografii?

Rodzaj dorobku w ogóle stanowiący podstawę oceny osiągnięć naukowych i twórczych jednostki naukowej określa §8 Rozporządzenia Ministra Nauki i Szkolnictwa Wyższego z dnia 27 października 2015 r. w sprawie kryteriów i trybu przyznawania kategorii naukowej jednostkom naukowym [Rozporządzenie, 2015b]. Obowiązki ewidencji w centralnej bibliografii wynikają m.in. z: Ustawy z dnia 11 lipca 2014 r. o zmianie ustawy Prawo o szkolnictwie wyższym oraz niektórych innych ustaw [Ustawa, 2014], Ustawy z dnia 30 kwietnia 2010 r. o zasadach finansowania nauki [Ustawa 2010], Rozporządzenia Ministra Nauki i Szkolnictwa Wyższego z dnia 29 czerwca 2015 r. w sprawie Systemu Informacji o Nauce [Rozporządzenie, 2015a].

\section{Przegląd stron internetowych bibliotek}

Mając na uwadze rozwój różnych źródeł informacji naukowej dokumentujących dorobek naukowców i obowiązek przekazywania tych danych przez uczelnie do Polskiej Bibliografii Naukowej, podjęto próbę rozpoznania procedury ewidencji dorobku piśmienniczego nauczycieli akademickich w bibliografii publikacji pracowników i repozytorium instytucjonalnym, na podstawie opublikowanych na stronach bibliotek uczelnianych aktów prawnych, ze szczególnym uwzględnieniem zarządzeń rektora, oraz informacji o wyżej wymienionych serwisach. Zasygnalizowano zarządzenia rektorskie ułatwiające wykonywanie analizy cytowań prac naukowych pracowników. Na potrzeby artykułu w lipcu 2016 roku dokonano przeglądu stron internetowych bibliotek wybranych uczelni technicznych:

- Politechnik: Białostockiej, Częstochowskiej, Gdańskiej, Koszalińskiej, Krakowskiej, Lubelskiej, Łódzkiej, Opolskiej, Poznańskiej, Rzeszowskiej, Śląskiej, Świętokrzyskiej, Warszawskiej, Wrocławskiej;

- AGH;

- uczelni, które wcześniej były politechnikami: Uniwersytetu Technologiczno-Humanistycznego w Radomiu (UTH), Uniwersytetu Technologiczno-Przyrodniczego w Bydgoszczy (UTP) i Zachodniopomorskiego Uniwersytetu Technologicznego w Szczecinie (ZUT).

\section{Wyniki badań i ich dyskusja}

Próbując odpowiedzieć na pytanie, kto prowadzi ewidencję dokumentów w bibliografii publikacji pracowników na uczelni, ustalono, że zadanie to należy do 
oddziałów informacji naukowej ${ }^{1}$ (w rozumieniu do bibliotek) w Politechnikach: Białostockiej, Częstochowskiej, Gdańskiej, Koszalińskiej, Lubelskiej, Opolskiej, Poznańskiej, Śląskiej, Świętokrzyskiej, Wrocławskiej oraz w AGH, UTH i UTP. Natomiast bibliotekarze nie wykonują tych czynności lub obok innych pracowników uczelni uczestniczą w ewidencji w Politechnikach: Krakowskiej, Łódzkiej, Rzeszowskiej, Warszawskiej oraz w ZUT. W bibliotekach Politechniki Łódzkiej i Warszawskiej baza Biblio została zamknięta i wykazuje w pierwszej instytucji dokumenty wydane w latach 1990-2014, a w drugiej włącznie do roku 2012. W pozostałych badanych instytucjach poza biblioteką dane do bibliografii obowiązkowo wprowadzają: na Politechnice Rzeszowskiej Samodzielna Sekcja Rozwoju Kadry Naukowej i pracownicy wskazani przez kierowników katedr lub zakładów wszystkich jednostek uczelni, zgodnie z zarządzeniem rektora tej uczelni [Zarządzenie RPR, 2010]; na Zachodniopomorskim Uniwersytecie Technologicznym w Szczecinie autorzy lub pracownicy upoważnieni przez kierującego jednostką międzywydziałową, zgodnie z zarządzeniem rektora [Zarządzenie RZUT, 2016a]; na Politechnice Krakowskiej im. Tadeusza Kościuszki autorzy posiadający aktywne konto w komputerowym systemie bibliotecznym, zgodnie z zarządzeniem rektora [Zarządzenie RPK, 2014]. Ponadto dostęp do wprowadzonych opisów mają: na Politechnice Rzeszowskiej kolejno kierownicy katedr lub zakładów oraz prodziekani do spraw nauki ostatecznie zatwierdzający dane [Zarządzenie RPR, 2010], w ZUT pracownicy Biblioteki Głównej sprawdzający opisy pod względem kompletności i poprawności zapisu danych w poszczególnych polach opisu oraz pracownicy wskazani przez kierującego jednostką międzywydziałową ostatecznie zatwierdzający dane w serwisie [Zarządzenie RZUT, 2016a], na Politechnice Krakowskiej pracownicy Biblioteki odpowiedzialni za poprawność opisów i wykonujący ich korektę [Zarządzenie RPK, 2014]. Zauważa się, że Biblioteka Politechniki Rzeszowskiej z mocy zarządzenia rektora nie została uprawniona do udostępnienia bibliografii na swojej stronie internetowej [Zarządzenie RPR, 2010] oraz że nie wykonuje żadnych czynności związanych z ewidencją zasobów.

Akty prawne w formie zarządzenia rektora dotyczące ewidencji dokumentów w bibliografii wyszukano na stronach bibliotek Politechnik: Krakowskiej, Lubelskiej, Opolskiej, Poznańskiej, Rzeszowskiej, Śląskiej, Warszawskiej, Wrocławskiej, w AGH i ZUT, a ich brak odnotowano w Politechnikach: Białostockiej, Częstochowskiej, Gdańskiej, Koszalińskiej, Łódzkiej, Świętokrzyskiej oraz w UTH i UTP. Biblioteka Politechniki Warszawskiej jako jedyna wśród badanych linkuje wszystkie uczelniane regulacje prawne (zakładka „Akty prawne”), w tym związane z działalnością biblioteki. Dzięki takim praktykom wiadomo dziś, jakie zasady ewidencji dokumentów obowiązywały w nieaktualizowanej od 2013 roku bibliografii.

1 Nazwa „oddział informacji naukowej” w strukturze organizacyjnej stopniowo ulega zmianie, wyodrębnione zostały m.in.: Oddział Informacji Naukowej i Promocji w Bibliotece Politechniki Opolskiej, Oddział Promocji i Informacji w Bibliotece Politechniki Łódzkiej, Oddział Systemów Komputerowych, Informacji Naukowej i Normalizacyjnej w Bibliotece Politechniki Świętokrzyskiej. 
We wszystkich zarządzeniach dotyczących bibliografii pracownicy zobowiązani zostali do rejestracji dorobku naukowego w serwisie. W zależności od uczelni prace przedkłada sam autor i/lub wyznaczona osoba. Analiza wyżej wymienionych aktów pokazała różnice istniejące między bibliotekami w organizacji procesu ewidencji dokumentów w bibliografii, wynikające m.in. z zapisów w zarządzeniu rektora, takich jak:

a) sprawdzanie przez autorów kompletności własnego dorobku w bazie i dostarczanie braków do Biblioteki, ustanowione zarządzeniem rektora Politechniki Lubelskiej [Zarządzenie RPL, 2013], zarządzeniem rektora Politechniki Poznańskiej [Zarządzenie RPP, 2013];

b) zobowiązanie pracowników do podania w celu zapisu w bibliografii wersji tytułu w języku angielskim w przypadku jego braku w publikacji, ustanowione zarządzeniem rektora Akademii Górniczo-Hutniczej [Zarządzenie RAGH, 2007];

c) ewidencja w bibliografii publikacji studentów uczelni na życzenie studenta, ale za zgodą prodziekana do spraw studenckich, ustanowiona zarządzeniem rektora Politechniki Lubelskiej [Zarządzenie RPL, 2013];

d) obowiązek zamieszczania w opisie bibliograficznym informacji, takich jak: wersja elektroniczna oryginału, link do strony zawierającej pełny tekst, skan publikacji wydanej w formie tylko drukowanej i jej przekazanie do biblioteki, ustanowione zarządzeniem rektora Zachodniopomorskiego Uniwersytetu Technologicznego w Szczecinie [Zarządzenie RZUT, 2016a];

e) przesyłanie danych z bibliografii do modułu sprawozdawczego przez pracownika biblioteki upoważnionego przez dziekanów wydziału, ustanowione zarządzeniem rektora Politechniki Opolskiej [Zarządzenie RPO, 2015].

Informację o nowych zasadach opracowania danych w bibliografii obowiązujące z tytułu współpracy uczelni z PBN, biblioteki zamieszczały także na stronach (zakładki „Aktualności” i związane z bibliografią) w formie m.in.: formularza uzupełnienia danych o publikacjach pracowników na podstawie Rozporządzenia Ministra Nauki i Szkolnictwa Wyższego z dnia 29 czerwca 2015 roku w sprawie Systemu Informacji o Nauce - w bibliotekach Politechnik Białostockiej i Lubelskiej; informacji o otwartym dostępie do publikacji (Open Access) według zarządzenia Ministra Nauki i Szkolnictwa Wyższego - w Politechnice Częstochowskiej; definicji arkusza wydawniczego i sposobu wyliczenia liczby arkuszy - w Politechnice Krakowskiej; zasad przekazywania do Biblioteki informacji o dorobku naukowym - w Politechnice Poznańskiej.

Spośród wielu informacji o bibliografii najczęściej poszukiwanych przez użytkowników są typy dokumentów rejestrowanych w bazie. Wykazy tych dokumentów znajdują się w zarządzeniach rektorów Politechnik: Lubelskiej, Opolskiej, Poznańskiej, Rzeszowskiej, Śląskiej, Wrocławskiej. W pozostałych wyszukanych zarządzeniach takiej informacji brak. Uwagę zwrócono na następujące wykazy:

a) W załączniku 1 do zarządzenia rektora Politechniki Wrocławskiej z 2016 roku wspomniany wykaz podzielony został na: 
- publikacje zaliczane do dorobku naukowego, [z rozgraniczeniem na] prace dokumentowane obowiązkowo i prace dokumentowane nieobowiązkowo;

- publikacje zaliczane do dorobku o charakterze nienaukowym (dokumentowane nieobowiązkowo), [stosowaną w bazie klasyfikację publikacji ze względu na] język i miejsce wydania;

- niepublikowany dorobek piśmienniczy, [z rozgraniczeniem na] prace dokumentowane obowiązkowo i prace dokumentowane nieobowiązkowo [Zarządzenie RPWr, 2016b].

b) W zarządzeniu rektora Politechniki Lubelskiej z 2013 roku spotykamy się $\mathrm{z}$ podziałem na:

- artykuły z czasopism naukowych i wydawnictw seryjnych; monografie, rozdziały/fragmenty monografii; podręczniki akademickie, skrypty; rozdziały, fragmenty podręczników/skryptów; referaty, komunikaty opublikowane w materiałach; recenzje opublikowane w czasopismach naukowych; zgłoszenia wynalazków, wzorów użytkowych, znaków towarowych opublikowane w Biuletynie Urzędu Patentowego; udzielone patenty na wynalazki, udzielone prawa ochronne na wzór użytkowy i znak towarowy, rejestracja wzoru przemysłowego, opublikowane w Wiadomościach Urzędu Patentowego; redakcja naukowa monografii i prac zbiorowych; redakcja naukowa czasopisma; redakcja podręcznika/skryptu naukowego;

- pozostałe publikacje, [w tym:] publikacje popularnonaukowe - książki, fragmenty; opracowania, wstępy/przedmowy, posłowia, tłumaczenia; wywiady, głosy w dyskusji, listy do redakcji; hasła w encyklopediach, słownikach; sprawozdania, komunikaty z konferencji i ich streszczenia [Zarządzenie RPL, 2013].

c) W zarządzeniu rektora Politechniki Rzeszowskiej z 2010 roku wspomniany wykaz zawiera oprócz publikacji inne osiągnięcia pracowników ewidencjonowane w bibliografii. Są to:

[...] udział w projektach badawczych, celowych, rozwojowych oraz umowy na wykonanie prac $\mathrm{B}+\mathrm{R}$; uzyskanie patentów, rejestrację wzorów użytkowych i przemysłowych; wdrożenia; opracowanie nowych produktów i technologii, na które uzyskano certyfikat; licencje; wystąpienia konferencyjne; członkostwo z wyboru w organizacji naukowej lub komitecie redakcyjnym o zasięgu światowym; uczestnictwo w międzynarodowych projektach naukowych [Zarządzenie RPR, 2010].

d) W zarządzeniu rektora Politechniki Opolskiej z 2015 roku wykaz obejmuje trzy typy dokumentów: publikacje w czasopismach naukowych, monografie naukowe, rozdziały w monografiach naukowych [Zarządzenie RPO, 2015].

Informacja o dokumentach rejestrowanych w bibliografii znajduje się, także w zakładce związanej z bibliografią w notce o serwisie w bibliotekach Politechnik: 
Białostockiej, Gdańskiej, Koszalińskiej, Krakowskiej, Łódzkiej, Poznańskiej, Rzeszowskiej, Śląskiej, Wrocławskiej, UTH i UTP.

Dokumenty stanowiące dorobek pracowników macierzystej uczelni są przedmiotem ewidencji w repozytorium instytucjonalnym w bibliotekach Politechnik: Krakowskiej, Łódzkiej, Poznańskiej, Śląskiej, Warszawskiej, Wrocławskiej oraz biblioteki UTP. W pozostałych jedenastu bibliotekach serwisu brak.

Akty prawne regulujące kwestie ewidencji w repozytorium udostępniono na stronach jako:

- zarządzenie rektora dotyczące repozytorium w Politechnikach: Poznańskiej, Śląskiej, Warszawskiej, Wrocławskiej i UTP;

- zarządzenie rektora w sprawie rozpraw doktorskich w Politechnice Krakowskiej i UTP (publicznie dostępny tylko tytuł i nr zarządzenia, pełny tekst w sieci lokalnej);

- uchwała Senatu w Politechnice Warszawskiej;

- regulamin repozytorium w Politechnikach Krakowskiej, Śląskiej oraz w UTP.

Osobami uprawnionymi do deponowania materiałów w repozytoriach są pracownicy uczelni, doktoranci, studenci. W UTP do grupy uprawnionych nie zaliczono studentów. Inny czynnik różnicujący badane biblioteki wynika z roli, jaką ten serwis odgrywa na uczelni.

W związku z tym, że w Politechnice Warszawskiej repozytorium prowadzone jest zamiast bibliografii, ustalono zakres czynności przypisany do Oddziału do spraw Bazy Wiedzy. Zadania ustanowione w formie zarządzenia rektora Politechniki Warszawskiej są następujące:

[...] bieżąca aktualizacja i dopisywanie danych wspólnych i formalnych, np.: tytułów czasopism, nazw serii, tytułów konferencji, punktacji publikacji wg bieżących zaleceń Ministerstwa Nauki i Szkolnictwa Wyższego, nazw jednostek PW, typów dokumentów, nazw języków; prowadzenie bieżącej korekty danych i udzielanie informacji o sposobie ich wprowadzania redaktorom wydziałowym, monitorowanie procesu archiwizacji utworów i wskazywanie braków w tym zakresie redaktorom i kierownikom jednostek PW [Zarządzenie RPW, 2015].

Szczególny rodzaj zbiorów na uczelni tworzą prace dyplomowe i rozprawy doktorskie. Prace dyplomowe zamieszcza się w repozytoriach Politechnik: Krakowskiej, Poznańskiej, Śląskiej, Warszawskiej na podstawie decyzji podejmowanych w poszczególnych jednostkach uczelni. Natomiast rozprawy doktorskie obowiązkowo archiwizuje się w repozytoriach Politechnik: Krakowskiej, Poznańskiej, Warszawskiej i w UTP, w tym dodatkowo udostępnia przed obroną w Politechnice Krakowskiej i Poznańskiej oraz UTP. Z analizy danych zamieszczonych na stronie Biblioteki Politechniki Śląskiej wynika, że ewidencja rozpraw doktorskich w tej instytucji nie jest prawnie uregulowana. $Z$ powodu braku zarządzenia/regulaminu w sprawie repozytorium/rozpraw doktorskich na stronie Biblioteki Politechniki Łódzkiej nie ustalono, jakie zasady ewidencji zostały przyjęte na tej uczelni. 
Powiększaniu zasobów w repozytorium Politechniki Wrocławskiej służy obligowanie autorów do deponowania prac powstałych na skutek podpisanej umowy o dzieło lub zlecenie z uczelnią, zgodnie z zarządzeniem [Zarządzenie RPWr, 2015] oraz prac podlegających rozliczeniu z uczelnią w związku z pobieraniem przez pracownika zwiększonego wynagrodzenia, zgodnie z zarządzeniem [Zarządzenie RPWr, 2016a].

Zarządzenia rektora upraszczające wykonywanie analiz cytowań dorobku naukowego nauczycieli akademickich regulują postępowanie pracowników według procedury: ,pracownik nowo zatrudniony w Uczelni na pierwszym etacie, posiadający dorobek naukowy zobowiązany jest przekazać do Oddziału Informacji Naukowej Biblioteki Głównej wykaz publikacji z lat wcześniejszych [...]" [Zarządzenie RPO, 2009], „od roku akademickiego 2016/2017 wprowadza się obowiązek wykonywania analizy cytowań prac indeksowanych nauczycieli akademickich ZUT wyłącznie według indywidualnego numeru identyfikacyjnego ResearcherID” [Zarządzenie RZUT, 2016b].

Zarządzenie w sprawie numeru ResearcherID zamieszczono także na stronie Biblioteki Politechniki Poznańskiej, ale z ograniczeniem do pełnego tekstu.

\section{Wnioski}

Ewidencja zasobów naukowych w bibliografii publikacji pracowników i repozytorium instytucjonalnym uległa zmianom i znajduje się w fazie ciągłego rozwoju. Zmiany wynikły na skutek decyzji podejmowanych na poziomie lokalnym i krajowym. Ogółem badane biblioteki można podzielić na dwie grupy: w pierwszej biblioteki na swych stronach publikują zarządzenia rek tora związane z ewidencją piśmienniczego dorobku naukowego pracowników w wyżej wymienionych serwisach, w drugiej biblioteki nie udostępniają takich informacji. W grupie pierwszej mieści się dziesięć bibliotek, co stanowi ponad połowę badanych instytucji.

Na podstawie informacji dostępnych na stronach bibliotek ustalono, kto zajmuje się opracowaniem dokumentów w tych serwisach. Dane do bibliografii publikacji pracowników uczelni zawsze wprowadzane były przez pracowników bibliotek w oddziale informacji naukowej. Obecnie obserwuje się zmiany koncepcji ewidencji w szkołach wyższych na rzecz udziału środowiska uczelni macierzystej. Wprowadzanie danych, ich sprawdzanie, zatwierdzanie w serwisach i przesyłanie do Modułu Sprawozdawczego PBN są dzielone z innymi osobami danej instytucji. W kilku badanych bibliotekach autorzy samodzielnie prowadzą ewidencję własnego dorobku naukowego w bibliografii publikacji pracowników.

Na obecnym etapie rozwoju bibliografia jest prowadzona równolegle $\mathrm{z}$ repozytorium instytucjonalnym lub zastąpiona przez ten serwis. Zarówno w bibliografii, jak i repozytorium coraz więcej informacji podlega ewidencji, $w$ tym nowe rodzaje dokumentów i nowe atrybuty opisywanych dokumentów. Zwiększeniu ulega liczba kategorii osób, których dokumenty są rejestrowane. 
Dostosowanie bibliografii do PBN spowodowało reorganizację procesu ewidencji zasobów naukowych na uczelniach i potrzebę organizacji transferu tych danych do Modułu Sprawozdawczego. Sposób ewidencji artykułów naukowych w czasopismach, monografii naukowych i rozdziałów w monografiach został ujednolicony. Zasady ewidencji dorobku naukowego pracowników uczelni wyższych stały się bardziej dostępne na stronach bibliotek. Odgórna regulacja w skali kraju sprzyja integracji rozproszonych zasobów naukowych w jednym miejscu w Internecie, a w przyszłości stwarza szansę na widoczność $\mathrm{PBN}$ w ramach innych projektów.

\section{Bibliografia}

Bednarek-Michalska B. (2013), Otwarte zasoby edukacyjne (OZE) na UMK, „Biuletyn EBIB”, 1, http://www.ebib.pl/images/stories/numery/137/137_michalska.pdf [dostęp: 22.07.2016].

Brzeziński P., Szewczuk K., Kiliszek W. (2016), Polska Bibliografia Naukowa, Modut Sprawozdawczy i system POL-index oczami dotychczasowego operatora systemu: nowości, wyzwania, podsumowanie, „Biuletyn EBIB”, 3,http://open.ebib.pl/ojs/index.php/ebib/article/view/432 [dostęp: 22.07.2016].

Cichoń S. (2013), Jakość kształcenia w szkole wyższej, Wydawnictwo Politechniki Częstochowskiej, Częstochowa.

Gajda J., Cichoń S. (2015), Problemy zarządzania współczesna uczelnią. Ujęcie wieloaspektowe, Wydawnictwo Wydziału Zarządzania Politechniki Częstochowskiej, Częstochowa.

Karwasińska E., Rychlik M. (2011), W kierunku uczelnianego repozytorium cyfrowego [w:] H. Hollender (red.), Cyfrowy świat dokumentu: wydawnictwa, biblioteki, muzea, archiwa, Centrum Promocji Informatyki, http://hdl.handle.net/10593/1797 [dostęp: 22.07.2016].

Knop U. (2014), Źródła informacji o wskaźnikach oceny czasopism w ofercie bibliotek wyższych szkót technicznych: wybrane zagadnienia [w:] E-eksplozja: narzędzia - metody użytkownicy. Konferencja naukowa, Biblioteka Jagiellońska, 27 marca 2014 r., Biblioteka Jagiellońska, Kraków, http://jbc.bj.uj.edu.pl/publication/290555 [dostęp: 22.07.2016].

Komunikat (2015), Komunikat w sprawie terminu wprowadzania danych i informacji do Systemu Informacji o Nauce w ramach Zintegrowanego Systemu Informacji o Nauce i Szkolnictwie Wyższym POL-on, http://www.nauka.gov.pl/g2/oryginal/2015_07/cd1bbba140db3271185d573b1009ec42.pdf [dostęp: 22.07.2016].

Kulczycki E. (2012), Polska Bibliografia Naukowa: pomyst dobry... [w:] idem, Warsztat badacza, http://ekulczycki.pl/warsztat_badacza/polska-bibliografia-naukowa-pomysl-dobry [dostęp: 22.07.2016].

Leja K. (2013), Zarządzanie uczelnią. Koncepcje i współczesne wyzwania, Oficyna a Wolters Kluwer business, Warszawa.

O nas, Polska Bibliografia Naukowa, https://pbn.nauka.gov.pl/sedno-webapp/about [dostęp: 22.07.2016].

Rozporządzenie (2015a), Rozporządzenie Ministra Nauki i Szkolnictwa Wyższego z dnia 29 czerwca 2015 roku w sprawie Systemu Informacji o Nauce, Dz.U. z 2015 r. poz. 944. 
Rozporządzenie (2015b), Rozporządzenie Ministra Nauki i Szkolnictwa Wyższego z dnia 27 października 2015 roku w sprawie kryteriów i trybu przyznawania kategorii naukowej jednostkom naukowym, Dz.U. z 2015 r. poz. 2015.

Sójkowska I., Barańska-Malinowska B. (2011), Bibliografia publikacji pracowników źródtem informacji wspomagajacej przygotowanie oceny jednostek naukowych [w:] H. Szarski, D. Dudziak (red.), III Wroctawskie Spotkania Bibliotekarzy, Oficyna Wydawnicza Politechniki Wrocławskiej, Wrocław.

Szczególowy opis formatu plików importu, Pomoc PBN, http://pbn-pomoc.opi.org.pl/index. php?option=com_content\&view=article\&id=217Itemid=279/=pl.\&lang=pl [dostęp: 22.07.2016].

Szymczak M. i in. (red.) (2002), Stownikjęzyka polskiego, t. 1, Wydawnictwo Naukowe PWN, Warszawa.

Ustawa (2010), Ustawa z dnia 30 kwietnia 2010 roku o zasadach finansowania nauki, Dz.U. z 2014 r. poz. 1620.

Ustawa (2014), Ustawa z dnia 11 lipca 2014 roku o zmianie ustawy Prawo o szkolnictwie wyższym oraz niektórych innych ustaw, Dz.U. z 2014 r. poz. 1198.

Zarządzenie RAGH (2007), Zarządzenie nr 17/2007 Rektora Akademii Górniczo-Hutniczej im. St. Staszica w Krakowie z dnia 30 marca 2007 roku w sprawie trybu rejestracji dorobku publikacyjnego pracowników Akademii Górniczo-Hutniczej, http://www.bg.agh.edu. $\mathrm{pl} /$ node/688 [dostęp: 22.07.2016].

Zarządzenie RPK (2014), Zarządzenie nr 16 Rektora Politechniki Krakowskiej im. Tadeusza Kościuszki z dnia 24 kwietnia 2014 r. znak R.0201-21/14 w sprawie ewidencji publikacji pracowników PK, http://suw.biblos.pk.edu.pl/opis_bazyBPP [dostęp: 22.07.2016].

Zarządzenie RPL (2013), Zarządzenie nr R-11/2013 Rektora Politechniki Lubelskiej z dnia 23 stycznia 2013 r. w sprawie dokumentowania publikacji pracowników Politechniki Lubelskiej, http://biblioteka.pollub.pl/o_bibliotece/akty_prawne [dostęp: 22.07.2016].

Zarządzenie RPO (2009), Zarządzenie nr 21/2009 Rektora Politechniki Opolskiej z dnia 11 marca 2009 r. w sprawie korzystania z wydawnictw zakupionych ze środków budżetowych dla potrzeb prowadzonych badań naukowych, prac rozwojowych, działalności dydaktycznej oraz gromadzenia materiałów konferencyjnych, publikacji pracowników i prac dyplomowych studentów Politechniki Opolskiej, https://bg.po.opole.pl/index.php/ pl/nauka/baza-publikacji-pracownikow-biblio [dostęp: 22.07.2016].

Zarządzenie RPO (2015), Zarządzenie nr 56/2015 Rektora Politechniki Opolskiej z dnia 17 grudnia 2015 r. w sprawie przekazywania informacji o publikacjach pracowników Politechniki Opolskiej do Systemu Informacji o Nauce poprzez Moduł Sprawozdawczy Polskiej Bibliografii Naukowej, https://bg.po.opole.pl/index.php/pl/nauka/baza-publikacji-pracownikow-biblio [dostęp: 22.07.2016].

Zarządzenie RPP (2013), Zarządzenie nr 19 Rektora Politechniki Poznańskiej z dnia 10 czerwca 2013 r. (RO/VI/19/2013) w sprawie obowiązku przekazywania do Biblioteki informacji o publikacjach pracowników Politechniki Poznańskiej w celu ich dokumentowania i udostępniania, http://library.put.poznan.pl/bib/index.html [dostęp: 22.07.2016].

Zarządzenie RPR (2010), Zarządzenie nr 14/2010 Rektora Politechniki Rzeszowskiej im. I. Łukasiewicza z dnia 31 marca 2010 r. w sprawie obowiązku rejestracji dorobku naukowego pracowników Politechniki Rzeszowskiej, http://biblio.prz.edu.pl/gfx/biblio/files/ aszcz/zarzadzenie_nr_14_2010__rektora_prz_z_31_03_2010.pdf [dostęp: 22.07.2016]. 
Zarządzenie RPW (2015), Zarządzenie nr 23/2015 Rektora Politechniki Warszawskiej z dnia 18 maja 2015 r. zmieniające zarządzenie nr 30/2009 Rektora PW w sprawie wprowadzenia regulaminu Organizacyjnego Biblioteki Głównej Politechniki Warszawskiej, https:// www.bip.pw.edu.pl/Wewnetrzne-akty-prawne/Dokumenty-Rektora-PW/Zarzadzenia-Rektora/2015/Zarzadzenie-Rektora-nr-23-2015-z-dnia-18-05-2015 [dostęp: 22.07.2016].

Zarządzenie RPWr (2015), Zarządzenie Wewnętrzne 21/2015 [Rektora Politechniki Wrocławskiej] z dnia 27 kwietnia 2015 r. zmieniające załącznik nr 1 do Zarządzenia Wewnętrznego 46/2014 w sprawie zawierania umów cywilnoprawnych w Politechnice Wrocławskiej, http://www.biblioteka.pwr.wroc.pl/RW_zwiekszone_wynagrodzenie,161.dhtml [dostęp: 22.07.2016].

Zarządzenie RPWr (2016a), Zarządzenie Wewnętrzne 9/2016 [Rektora Politechniki Wrocławskiej] z dnia 19 stycznia 2016 r. w sprawie możliwości zwiększenia w roku 2016 wynagrodzeń pracowników Uczelni, http://www.biblioteka.pwr.wroc.pl/RW_zwiekszone_wynagrodzenie,161.dhtml [dostęp: 22.07.2016].

Zarządzenie RPWr (2016b), Zarządzenie Wewnętrzne 50/2016 [Rektora Politechniki Wrocławskiej] z dnia 18 kwietnia 2016 w sprawie dokumentowania i rozpowszechniania wyników badań naukowych Politechniki Wrocławskiej. Załącznik nr 1, http://www.biblioteka. pwr.wroc.pl/2184902.dhtml [dostęp: 22.07.2016].

Zarządzenie RZUT (2016a), Zarządzenie nr 21 Rektora Zachodniopomorskiego Uniwersytetu Technologicznego w Szczecinie z dnia 7 kwietnia 2016 r. w sprawie dokumentowania publikacji naukowych pracowników i doktorantów ZUT w systemie Uczelnia.XP, http:// www.bg.zut.edu.pl/pliki/p1_m0_176.pdf [dostęp: 22.07.2016].

Zarządzenie RZUT (2016b), Zarządzenie nr 24 Rektora Zachodniopomorskiego Uniwersytetu Technologicznego w Szczecinie z dnia 18 kwietnia 2016 r. w sprawie rejestracji indywidualnego numeru ResearcherID w bazie Web of Science przez nauczycieli akademickich ZUT, http://www.bg.zut.edu.pl/dokumentacja-dorobku-naukowego-zarzadzenie-rektora-zut-nr-24-z-180416-r.html [dostęp: 22.07.2016]. 